\title{
Leptin Receptor Gene Gln223Arg Polymorphism Is Not Associated with Hypertension: A Preliminary Population-Based Cross-Sectional Study
}

\author{
Geórgia das Graças Pena, ${ }^{1}$ Andre L. S. Guimarães, ${ }^{2}$ Rosângela R. Veloso, ${ }^{2}$ Tatiana C. Reis, ${ }^{2}$ \\ Crizian S. Gomes, ${ }^{1}$ João F. R. Neto, ${ }^{2}$ and Gustavo Velasquez-Melendez ${ }^{1}$ \\ ${ }^{1}$ Maternal-Child Nursing and Public Health Department of the Nursing School, Nursing School, Federal University of Minas Gerais, \\ (UFMG), 30130-100 Belo Horizonte, MG, Brazil \\ ${ }^{2}$ Department of Dentistry, Program in Health Sciences, State University of Montes Claros (UNIMONTES), 39401-001Montes Claros, \\ MG, Brazil
}

Correspondence should be addressed to Gustavo Velasquez-Melendez; jguveme@gmail.com

Received 20 September 2013; Accepted 11 November 2013; Published 13 February 2014

Academic Editor: Michael S. Wolin

Copyright (c) 2014 Geórgia das Graças Pena et al. This is an open access article distributed under the Creative Commons Attribution License, which permits unrestricted use, distribution, and reproduction in any medium, provided the original work is properly cited.

\begin{abstract}
Hypertension is responsible for high morbidity and mortality as one of the most important cardiometabolic risk factors. The aim of the study was to investigate whether the Gln223Arg in the leptin receptor (LEPR) influences the prevalence of hypertension. A cross-sectional study was carried out in individuals aged $\geq 18$ years. Polymorphism identification was performed using PCRRFLP analysis. Participants with blood pressure $\geq 140 / 90 \mathrm{mmHg}$ or medication use were considered hypertensive. Frequencies, means, cross-tabulations, and multivariate models were produced to study differences in hypertension prevalence by genotypes. The study includes 470 participants. The frequency of GG polymorphism variant was $10.43 \%, 46.81 \%$ AG, and $42.77 \%$ AA. The distribution of hypertension frequency by LEPR genotypes was the following: AA 43.8\%, AG 40.4\%, and GG 40.8\%; there were no significant differences between groups. Comparative analysis which used multivariate Poisson regression adjusted by many potential confounders (age, sex, schooling, smoking, alcohol intake, obesity, and family history of parental obesity) did not modify this result. In this large sample of population-based study, the association of the LEPR Gln223Arg gene polymorphism with hypertension was not observed.
\end{abstract}

\section{Introduction}

Cardiometabolic outcomes are responsible for high mortality worldwide both in developed and developing societies [1,2]. Among the top ten causes of death, two are cardiovascular diseases (CVD) and responsible for $12.8 \%$ of the deaths in the world [3].

Moreover, CVD are related to complex phenotypes with multifactorial etiology such as obesity, uncontrolled blood pressure, increased waist circumference, increased fractions of LDL and triglycerides, decreased HDL [2, 4-9], presence of metabolic syndrome [10-12], diabetes [13], and genetic polymorphisms [14]. These complex phenotypes contribute to the increase of the prevalence of CVD and increasing the costs in the public health [15].
Therefore, studies which investigate the association of these complex phenotypes, such as cardiometabolic risk factors, take on a definite importance in the context of public health and the search of different analysis tools such as evaluation of polymorphisms. These are interesting strategies to understand the contribution of the epidemiology of CVD better.

The mechanism of leptin signaling in the regulation of energy homeostasis in human metabolism [16] is considered of utmost importance. Besides the leptin gene receptor, polymorphism possibly intermeddles with the regulation of body weight, obesity, fat mass distribution, serum leptin levels, glucose homeostasis, and diabetes, among others [17-24].

The variants of the leptin receptor Gln223Arg gene (LEPR Gln223Arg) have been reported to associate with metabolic 
functions and adiposity in different studies, contribute to inadequate metabolism of the hormone, and affect the biological functions and leptin resistance $[19,21,24,25]$. Thus, this polymorphism could be involved as a genetic risk factor in overweight and other cardiometabolic events [17, 20, 2224]. Evidence of a significant effect of the Gln223Arg polymorphism on blood pressure regulation has been reported in some recent studies $[21,26,27]$. The aim of the study was to study the association of the LEPR Gln223Arg with prevalence of hypertension in an urban Brazilian population.

\section{Methods}

2.1. Study Population and Design. A cross-sectional population-based study was conducted with residents aged $\geq 18$ years in Montes Claros, Minas Gerais, Brazil. Montes Claros now has about 361.915 inhabitants-95.1\% of them in the urban municipality area [28].

2.2. Sample Design. This research proposes the sample size procedure for estimating the prevalence of the LEPR Gln223Arg. The sample size was based on the expected prevalence of $10 \%$ of the less frequent polymorphism with the standard deviation of 1.55 and variation coefficient of $15 \%$. In the first stage, the database of census tracts (2010 Census, IBGE) [28] was used for drawing the primary sampling units. In the second stage, the address list for the purpose of drawing households and all individuals in the survey asked to participate in the study will be used.

2.3. Data Collection. An interview was conducted by answering a face-to-face survey questionnaire covering various aspects of their demographic (sex, age, skin color, marital status, and schooling) and lifestyle characteristics (physical activity, smoking habits, and alcohol consumption). At the conclusion of the interview, a clinical evaluation of participants was performed; this included weight, height, waist circumference, and blood pressure measurements, carried out threefold, by well-trained staff in keeping with standard procedures $[29,30]$.

Anthropometric variables were measured as suggested in the recommendations of the World Health Organization [30] and included all eligible participants in the selected households. For the adults, overweight was defined as BMI $\geq$ $25 \mathrm{~kg} / \mathrm{m}^{2}$ and obese as BMI $\geq 30 \mathrm{~kg} / \mathrm{m}^{2}$. Waist circumference (WC) was measured to the nearest millimeter, using a nonextendable measuring tape, and taken exactly halfway between the margin of the lowest rib and the iliac crest. The participants were in a standing position (accurate to $0.1 \mathrm{~cm}$ ).

The capillary whole blood was obtained without fasting from a finger prick and was immediately analyzed with the use of a Performa (Roche Diagnostic Systems ${ }^{\odot}$, Nutley, NJ, USA) blood glucose analyzer. Participants were considered normal at less than $140 \mathrm{mg} / \mathrm{dL}$ or high when greater than or equal to $140 \mathrm{mg} / \mathrm{dL}$.

Blood pressure was measured, using an ONRON HEM742INT ${ }^{\odot}$ automatic BP monitor, in the sitting position, using the right upper arm and an appropriately sized cuff after a 5 min interval, according to The Seventh Report of the Joint
National Committee on Prevention, Detection, Evaluation, and Treatment of High Blood Pressure [29]. Measurements were performed three times in the participant's right arm with a two-minute interval, after a rest period of at least five minutes. Hypertension was defined as a systolic blood pressure greater than or equal to $140 \mathrm{mmHg}$ and/or a diastolic blood pressure greater than or equal to $90 \mathrm{mmHg}$ or reported use of medication for hypertension control [29].

2.4. DNA Extraction and Genotyping. The collection of genomic DNA was obtained through an oral swab performed with a sterile plastic spatula. After gentle scraping of oral mucosa, the tip of the spatula was immersed in $2 \mathrm{~mL}$ sterile microtubes containing $1500 \mathrm{~mL}$ of Krebs buffer $(\mathrm{NaCl}$ $20 \%, \mathrm{KCl} 2 \%, \mathrm{CaCl}_{2}, 2 \%, \mathrm{H}_{2} \mathrm{O} 2 \%, \mathrm{MgSO}_{4}, \mathrm{KH}_{2} \mathrm{PO}_{4}$, and $\mathrm{C}_{6} \mathrm{H}_{12} \mathrm{O}_{6}$ ) and stored at $-20^{\circ} \mathrm{C}$ in the Laboratory of Health Research, Universidade Estadual de Montes Claros for future DNA extraction. DNA extraction was carried out by protocol described earlier [31, 32].

Gln223Arg (rs1137101) polymorphisms were assessed by PCR amplification and digestion. The primers used were $5^{\prime}$-ACCCTTTAAGCTGGGTGTCCCAAATAG- $3^{\prime}$ and $5^{\prime}$ CAATATTTATGGGCTGAACTGACATT- $3^{\prime}$ primers. For amplification and genotyping, $100 \mathrm{ng}$ of DNA was amplified using primers specific to 10 pmol of primers: forward, $2.5 \mu \mathrm{L}$, dNTP mix (25 mM of each), $2.5 \mu \mathrm{L}$ 10X PCR buffer, $1.25 \mu \mathrm{L}$ magnesium chloride $(50 \mathrm{mM})$, and 2.5 units of Platinum Taq DNA polymerase (Invitrogen ${ }^{(}$Life Technologies, Carlsbad, USA). The conditions for the PCR assay were denaturation at $95^{\circ} \mathrm{C}$ for $5 \mathrm{~min}$ followed by 35 cycles of denaturation at $95^{\circ} \mathrm{C}$ for $1 \mathrm{~min}$, annealing at $57.4^{\circ} \mathrm{C}$ for $1 \mathrm{~min}$, and extension at $72^{\circ} \mathrm{C}$ for $1 \mathrm{~min}$, and a final extension at $72^{\circ} \mathrm{C}$ for $10 \mathrm{~min}$. This primer pair produced a fragment of $330 \mathrm{bp}$. The $330 \mathrm{bp}$ PCR product was digested using the MspI restriction endonuclease (Promega ${ }^{\circledR}$, Madison, WI, USA). The substitution from A to $G$ allele produce a single cut site yielding two bands of 293 and $37 \mathrm{bp}$.

2.5. Statistical Analyses. Studied population characteristics were presented by the absolute and relative frequencies of the demographic and life style variables stratified by sex. Statistical differences were evaluated by Pearson's chi-square test, and the significance level was set at 5\% $(P<0.05)$. First, sample distributions of the sociodemographic variables (age, sex, schooling, smoking, alcohol intake, obesity and family history of parental obesity, family income, nutritional, and marital status) according to genotype Gln223arg polymorphism were estimated. Subsequently, associations between Gln223arg polymorphism and hypertension were explored with the use of crude prevalence ratios (PR) with $95 \%$ confidence intervals; a logistic regression model was used. Adjusted PR for potential confounders were obtained using a multivariable Poisson regression model including all variables. All analyses were conducted in Stata version 12.0 software, StataCorp ${ }^{\circledR}$, Texas, USA.

2.6. Ethics Committee Approval. This study was approved by the Research Ethics Committee of Universidade Federal de Minas Gerais (UFMG), in accordance with National Health 
TABLE 1: Sociodemographic characteristics by sex. Montes Claros, Brazil, 2013.

\begin{tabular}{|c|c|c|c|c|c|c|c|}
\hline \multirow{3}{*}{ Variable } & \multicolumn{4}{|c|}{ Sex } & \multicolumn{2}{|c|}{ Total } & \multirow{3}{*}{$P$ value* } \\
\hline & \multicolumn{2}{|c|}{ Male } & \multicolumn{2}{|c|}{ Female } & & & \\
\hline & $n$ & $\%$ & $n$ & $\%$ & $n$ & $\%$ & \\
\hline Age groups (years) & & & & & & & 0.472 \\
\hline $18-29$ & 40 & 24.84 & 79 & 25.57 & 119 & 25.32 & \\
\hline $30-39$ & 30 & 18.63 & 52 & 16.83 & 82 & 17.45 & \\
\hline $40-49$ & 20 & 12.42 & 58 & 18.77 & 78 & 16.60 & \\
\hline $50-59$ & 34 & 21.12 & 56 & 18.12 & 90 & 19.15 & \\
\hline$\geq 60$ & 37 & 22.98 & 64 & 20.71 & 101 & 21.49 & \\
\hline Skin color & & & & & & & 0.061 \\
\hline White & 26 & 16.25 & 73 & 23.70 & 99 & 21.15 & \\
\hline Nonwhite & 134 & 83.75 & 235 & 76.30 & 369 & 78.85 & \\
\hline Marital status & & & & & & & $<0.001$ \\
\hline With spouse & 106 & 65.84 & 140 & 45.31 & 246 & 52.34 & \\
\hline Without spouse & 55 & 34.16 & 169 & 54.69 & 224 & 47.66 & \\
\hline Education (years) & & & & & & & 0.410 \\
\hline $0-5$ & 19 & 11.88 & 52 & 16.88 & 71 & 15.17 & \\
\hline $6-7$ & 68 & 42.50 & 118 & 38.31 & 186 & 39.74 & \\
\hline $8-11$ & 24 & 15.00 & 38 & 12.34 & 62 & 13.25 & \\
\hline$\geq 12$ & 49 & 30.62 & 100 & 32.47 & 149 & 31.84 & \\
\hline Income (minimum wages) & & & & & & & 0.251 \\
\hline$<2$ & 25 & 15.53 & 44 & 14.29 & 69 & 14.71 & \\
\hline $2-3$ & 74 & 45.96 & 121 & 39.29 & 195 & 41.58 & \\
\hline$\geq 4$ & 62 & 38.51 & 143 & 46.42 & 205 & 43.71 & \\
\hline Physical activity & & & & & & & 0.089 \\
\hline Yes & 113 & 70.19 & 239 & 77.35 & 352 & 74.89 & \\
\hline Inactive & 48 & 29.81 & 70 & 22.65 & 118 & 25.11 & \\
\hline Smoking & & & & & & & $<0.001$ \\
\hline Yes & 32 & 20.00 & 16 & 5.23 & 48 & 10.30 & \\
\hline Ex-smoking & 43 & 26.87 & 35 & 11.44 & 78 & 16.74 & \\
\hline No & 85 & 53.13 & 255 & 83.33 & 340 & 72.96 & \\
\hline Alcohol intake & & & & & & & 0.013 \\
\hline Yes & 60 & 37.27 & 81 & 26.21 & 141 & 30.00 & \\
\hline No & 101 & 62.73 & 228 & 73.79 & 329 & 70.00 & \\
\hline
\end{tabular}

${ }^{*} P$ value $<0.05$ for differences between male and female (chi-square test).

Council Resolution 196/96. All of the subjects who took part in the study were informed about the objectives of the research and their rights as participants, and then they were asked to sign a consent form.

\section{Results}

In the preliminary results, sample size was 470 participants, $34.2 \%$ (161) males and 65.7\% (309) females. The mean and standard deviation of age with average age of total population was $44.72 \pm 17.99$ years. Selected demographic characteristics according to sex are shown in Table 1 . The age group with the highest frequency was 18 to 29 years $25 \%$ (119) followed by age greater or equal to 60 years $21 \%$ (101). Frequencies of schooling equal to or greater than 9 years of education and income were similar between the sexes. There were no statistical differences in sociodemographic characteristics between sexes, except for the marital status. Regarding the married status (with spouse), the highest frequency was observed in men $(65.8 \%)$ than women $(45.3 \% ; P<0.001)$. For the lifestyle habits, the consumption of alcohol and tobacco was higher in the male group $(P<0.05)$.

Table 2 shows high prevalence of abdominal obesity among the women. Prevalence of nutritional status, hypertension, and glucose levels was similar between sexes. The genotypes of Gln223Arg polymorphism in the LEPR gene distribution were the following: GG polymorphism variant was $10.43 \%(n=49), 46.81 \%$ AG $(n=220)$, and $42.77 \%$ AA $(n=201)$.

In the univariate analysis, carriers of genotype AA presented a slightly higher prevalence of hypertension (43.78\%) when compared to those who have GG genotype (40.8\%). The prevalence ratios were not significant $(\mathrm{RP}=1.07$; $\mathrm{CI}$ 95\%: 0.73-1.55). The distribution of hypertension frequency 
TABLE 2: Nutritional status, glucose levels, and blood pressure status by sex. Montes Claros, Brazil, 2013.

\begin{tabular}{|c|c|c|c|c|c|c|c|}
\hline \multirow{3}{*}{ Variables } & \multicolumn{4}{|c|}{ Sex } & \multicolumn{2}{|c|}{ Total } & \multirow{3}{*}{$P$ value* } \\
\hline & \multicolumn{2}{|c|}{ Male } & \multicolumn{2}{|c|}{ Female } & \multirow[b]{2}{*}{$n$} & \multirow[b]{2}{*}{$\%$} & \\
\hline & $n$ & $\%$ & $n$ & $\%$ & & & \\
\hline Nutritional status & & & & & & & 0.099 \\
\hline Underweight & 08 & 4.97 & 13 & 4.23 & 21 & 4.49 & \\
\hline Normal weight & 73 & 45.34 & 123 & 40.07 & 196 & 41.88 & \\
\hline Overweight & 54 & 33.54 & 90 & 29.32 & 144 & 30.77 & \\
\hline Obese & 26 & 16.15 & 81 & 26.38 & 107 & 22.86 & \\
\hline Abdominal obesity & & & & & & & $<0.001$ \\
\hline No & 135 & 83.85 & 178 & 57.79 & 313 & 66.74 & \\
\hline Yes & 26 & 16.15 & 130 & 42.21 & 156 & 33.26 & \\
\hline Hypertension & & & & & & & 0.632 \\
\hline Yes & 96 & 59.63 & 176 & 57.33 & 272 & 58.12 & \\
\hline No & 65 & 40.37 & 131 & 42.67 & 196 & 41.88 & \\
\hline Glucose level & & & & & & & 0.574 \\
\hline Normal (<140 mg/dL) & 137 & 85.09 & 267 & 86.97 & 404 & 86.32 & \\
\hline $\operatorname{High}(\geq 140 \mathrm{mg} / \mathrm{dL})$ & 24 & 14.91 & 40 & 13.03 & 64 & 13.68 & \\
\hline
\end{tabular}

${ }^{*} P<0.05$ for differences between male and female (chi-square test).

by genotypes LEPR was the following by group: AA $43.8 \%$ $(n=88)$, AG $40.4 \%(n=88)$, and GG $40.8 \%(n=20)$; there were no significant differences between groups $(P=0.76)$.

Comparative analysis using multivariate Poisson regression adjusted by many potential confounders (age, sex, schooling, smoking, alcohol intake, waist circumference, glucose levels, and obesity and family history of parental obesity) did not modify this result. According to the multivariable Poisson regression model, genotypes of Gln223Arg polymorphism did not remain significantly associated with hypertension in various multivariate models $(\mathrm{PR}=0.95$; 95\% CI: 0.70-1.27) after adjustment for age, sex, schooling, smoking, alcohol intake, waist circumference, and parental obesity history (Table 3 ).

\section{Discussion}

In this population-based study, the frequencies of LEPR Gln223Arg and the association between genotype frequencies and the mild levels of blood pressure were estimated. Thus by far, this is the first population-base study describing a genotype frequency of the LEPR Gln223Arg variant in healthy populations of Brazil. The genotype frequencies of three categories of polymorphism studied correspond to 10,47 , and $42 \%$ for $\mathrm{GG}, \mathrm{AG}$, and $\mathrm{AA}$, respectively. This is rather dissimilar to recent studies carried out in healthy American multiethnic population (African, AfricanAmerican, African-Caribbean, Caucasian, Asian, and other ethnic groups) in which the frequencies is diverse. For example, AA ranged from $13.4 \%$ in African-Caribean to $37.9 \%$ in Caucasian, while the GG ranged from $14.16 \%$ in Caucasian to $34.62 \%$ in Asian/other minority ethnic groups. However, the genotype frequencies founded are more similar with the Caucasians [33].
Several lines of evidence suggest that most of the polymorphisms associated with signaling impairment of leptin action in the central level would correspond to Gln223Arg polymorphism and in turn be associated with high circulating of leptin levels, and this may play a role in the pathophysiology of hypertension obese $[20,22]$. The mechanism that explains the relationship between obesity and hypertension could be mediated by the increase of sympathetic nervous system activity.

According to recent studies, positive relationships between plasma leptin and 24-hour blood pressure levels have been shown. In a cross-sectional study in a population of 70 nondiabetic, normotensive, and obese women, serum leptin levels were directly related to 24-hour blood pressure levels aside BMI; this evinces that leptin levels could be a crucial parameter for determining the blood pressure level [34]. Obesity-induced hypertension could be secondary to insulin resistance and/or hyperinsulinemia [35]. In obese hypertensive subjects, changes in serum leptin levels correlated to changes in blood pressure levels after weight loss regardless of insulin resistance confirming the role of leptin in the pathophysiology of hypertension in obese patients [36].

The relationship between serum leptin levels was also shown in hypertensive participants. After adjustment for confounders, the authors concluded that free leptin surrogates are associated with masked hypertension in nonobese normoglycemic subjects. Following the same lines of evidence, in a study of 284 volunteers with various levels of waist to hip ratio, the differences in blood pressure by LEPR variants remained significant after adjusting for the influence of obesity and body fat distribution, as well as insulin and leptin [21].

In this study, no association between Gln223Arg polymorphism and hypertension is reported. This association 
TABLE 3: Multivariate Poisson regression model (prevalence ratio and 95\% CI) for hypertension, Montes Claros, Brazil, 2013.

\begin{tabular}{|c|c|c|c|}
\hline Models & $\mathrm{PR}$ & $95 \% \mathrm{CI}$ & $P$ value \\
\hline \multicolumn{4}{|l|}{ Model 1} \\
\hline Genotype GG* & 1 & - & - \\
\hline Genotype AG & 0.98 & $0.68-1.43$ & 0.954 \\
\hline Genotype AA & 1.07 & $0.73-1.55$ & 0.712 \\
\hline \multicolumn{4}{|c|}{ Model 2 (adjust: age) } \\
\hline Genotype AG & 1.02 & $0.75-1.38$ & 0.887 \\
\hline Genotype AA & 0.98 & $0.72-1.33$ & 0.919 \\
\hline \multicolumn{4}{|c|}{ Model 3 (adjust: age and sex) } \\
\hline Genotype AG & 1.00 & $0.75-1.38$ & 0.895 \\
\hline Genotype AA & 0.97 & $0.72-1.32$ & 0.891 \\
\hline \multicolumn{4}{|c|}{ Model 4 (adjust: age, sex, and education) } \\
\hline Genotype AG & 1.02 & $0.75-1.39$ & 0.868 \\
\hline Genotype AA & 0.97 & $0.72-1.32$ & 0.881 \\
\hline \multicolumn{4}{|c|}{ Model 5 (adjust: age, sex, education, and smoke) } \\
\hline Genotype AG & 1.04 & $0.75-1.43$ & 0.801 \\
\hline Genotype AA & 0.98 & $0.72-1.35$ & 0.941 \\
\hline \multicolumn{4}{|c|}{ Model 6 (adjust: age, sex, education, smoke, and alcohol intake) } \\
\hline Genotype AG & 1.04 & $0.75-1.42$ & 0.808 \\
\hline Genotype AA & 0.98 & $0.72-1.35$ & 0.938 \\
\hline \multicolumn{4}{|c|}{ Model 7 (adjust: age, sex, education, smoke, alcohol intake, and WC) } \\
\hline Genotype AG & 1.03 & $0.75-1.43$ & 0.808 \\
\hline Genotype AA & 0.99 & $0.72-1.35$ & 0.938 \\
\hline \multicolumn{4}{|c|}{$\begin{array}{l}\text { Model } 8 \text { (adjust: age, sex, education, smoke, alcohol intake, WC, and } \\
\text { parental obesity history) }\end{array}$} \\
\hline Genotype AG & 1.02 & $0.75-1.38$ & 0.862 \\
\hline Genotype AA & 0.95 & $0.70-1.27$ & 0.748 \\
\hline
\end{tabular}

* GG genotype as reference group. WC: waist circumference.

remained nonsignificant after controlling for many potential confounders and measuring leptin levels that were not measured. It is known that casual blood pressure level does not account for the blood pressure circadian oscillation and this lack of precision in the measurements of blood pressure could explain the nonassociation between polymorphism and hypertension [37].

The results should be interpreted cautiously since the preliminary data results are about a complex sample and need weighing adjustments for different probabilities of selection of each participant.

In conclusion, this study does not provide evidence for a role of the LEPR gene Gln223Arg polymorphism in increasing the prevalence of mild hypertension in a cross-sectional population-based study. Thus, this study failed to provide evidence for a differential prevalence of mild hypertension by groups of the LEPR Q223R gene polymorphism.

\section{Conflict of Interests}

The authors declare that there is no conflict of interests regarding the publication of this paper.

\section{Authors' Contribution}

Gustavo Velasquez-Melendez, João F. R. Neto, Geórgia das Graças Pena, and Andre L. S. Guimarães designed the research; Gustavo Velasquez-Melendez, João F. R. Neto, Geórgia das Graças Pena, Rosângela R. Veloso, and Tatiana C. Reis conducted the research; Gustavo Velasquez-Melendez, Geórgia das Graças Pena, Crizian S. Gomes, and Andre L. S. Guimarães analyzed the data; Gustavo Velasquez-Melendez, João F. R. Neto, Geórgia das Graças Pena, and Andre L. S. Guimarães wrote the paper. Gustavo Velasquez-Melendez and Geórgia das Graças Pena had primary responsibility for final content. All authors read and approved the final paper. All authors contributed to conception, design, and paper preparation, read, and approved the final manuscript. All authors abide by the Association for Medical Ethics (AME) ethical rules of disclosure.

\section{Acknowledgments}

This study was supported by Grant (EFP_00001409) from the Fundação de Amparo a Pesquisa do Estado de Minas Gerais 
(FAPEMIG). Dr. Guimarães and Dr. Velasquez-Melendez are research fellow of CNPq (Conselho Nacional de Desenvolvimento Científico e Tecnológico).

\section{References}

[1] A. O. Odegaard, W. P. Koh, J. Yuan, M. D. Gross, and M. A. Pereira, "Western-style fast food intake and cardiometabolic risk in an Eastern country," Circulation, vol. 126, pp. 182-188, 2012.

[2] L. Pérusse, J.-P. Després, A. Tremblay et al., "Genetic and environmental determinants of serum lipids and lipoproteins in French Canadian families," Arteriosclerosis, vol. 9, no. 3, pp. 308-318, 1989.

[3] WHO, The Top 10 Causes of Death, World Health Organization, Geneva, Switzerland, 2011.

[4] J. D. Brunzell and A. F. Ayyobi, "Dyslipidemia in the metabolic syndrome and type 2 diabetes mellitus," The American Journal of Medicine, vol. 115, no. 8, supplement 1, pp. 24-28, 2003.

[5] K. L. Edwards, M. C. Mahaney, A. G. Motulsky, and M. A. Austin, "Pleiotropic genetic effects on LDL size, plasma triglyceride, and HDL cholesterol in families," Arteriosclerosis, Thrombosis, and Vascular Biology, vol. 19, no. 10, pp. 2456-2464, 1999.

[6] M. F. Feitosa, T. Rice, T. Rankinen et al., "Common genetic and environmental effects on lipid phenotypes: the HERITAGE family study," Human Heredity, vol. 59, no. 1, pp. 34-40, 2005.

[7] J. E. Hokanson, C. D. Langefeld, B. D. Mitchell et al., "Pleiotropy and heterogeneity in the expression of atherogenic lipoproteins: the IRAS family study," Human Heredity, vol. 55, no. 1, pp. 4650, 2003.

[8] L. F. Marcopito, S. S. F. Rodrigues, M. A. Pacheco, M. M. Shirassu, A. J. Goldfeder, and M. A. de Moraes, "Prevalência de alguns fatores de risco para doenças crônicas na cidade de São Paulo," Revista de Saúde Pública, vol. 39, pp. 738-745, 2005.

[9] G. Velásquez-Meléndez, F. C. Parra, A. Gazzinelli, S. WilliamsBlangero, and R. Correa-Oliveira, "Genetic determinants of risk factors for cardiovascular disease in a population from rural Brazil," Human Biology, vol. 79, no. 2, pp. 179-190, 2007.

[10] A. Laws, M. L. Stefanick, and G. M. Reaven, "Insulin resistance and hypertriglyceridemia in nondiabetic relatives of patients with noninsulin-dependent diabetes mellitus," Journal of Clinical Endocrinology and Metabolism, vol. 69, no. 2, pp. 343-347, 1989.

[11] M. C. Schumacher, T. M. Maxwell, L. L. Wu, S. C. Hunt, R. R. Williams, and S. C. Elbein, "Dyslipidemias among normoglycemic members of familial NIDDM pedigrees," Diabetes Care, vol. 15, no. 10, pp. 1285-1289, 1992.

[12] W. Tang, Y. Hong, M. A. Province et al., "Familial clustering for features of the metabolic syndrome: the National Heart, Lung, and Blood Institute (NHLBI) Family Heart Study," Diabetes Care, vol. 29, no. 3, pp. 631-636, 2006.

[13] A. Malhotra and J. K. Wolford, "Analysis of quantitative lipid traits in the genetics of NIDDM (GENNID) study," Diabetes, vol. 54, no. 10, pp. 3007-3014, 2005.

[14] S. H. Shah, "Gene polymorphisms and susceptibility to coronary artery disease," Pediatric Blood and Cancer, vol. 48, no. 7, pp. 738-741, 2007.

[15] M. I. R. Azambuja, M. Foppa, M. F. Maranhão, and A. C. Achutti, "Impacto econômico dos casos de doença cardiovascular grave no Brasil: uma estimativa baseada em dados secundários," Arquivos Brasileiros de Cardiologia, vol. 91, pp. 163-171, 2008.

[16] N. A. Tritos and C. S. Mantzoros, "Leptin: its role in obesity and beyond," Diabetologia, vol. 40, no. 12, pp. 1371-1379, 1997.

[17] Y. C. Chagnon, W. K. Chung, L. Pérusse, M. Chagnon, R. L. Leibel, and C. Bouchard, "Linkages and associations between the leptin receptor (LEPR) gene and human body composition in the Quebec family study," International Journal of Obesity and Related Metabolic Disorders, vol. 23, no. 3, pp. 278-286, 1999.

[18] T. A. Lakka, T. Rankinen, S. J. Weisnagel et al., "Leptin and leptin receptor gene polymorphisms and changes in glucose homeostasis in response to regular exercise in nondiabetic individuals: the HERITAGE family study," Diabetes, vol. 53, no. 6, pp. 1603-1608, 2004.

[19] V. S. Mattevi, V. M. Zembrzuski, and M. H. Hutz, "Association analysis of genes involved in the leptin-signaling pathway with obesity in Brazil," International Journal of Obesity and Related Metabolic Disorders, vol. 26, no. 9, pp. 1179-1185, 2002.

[20] N. D. Quinton, A. J. Lee, R. J. M. Ross, R. Eastell, and A. I. F. Blakemore, "A single nucleotide polymorphism (SNP) in the leptin receptor is associated with BMI, fat mass and leptin levels in postmenopausal Caucasian women," Human Genetics, vol. 108, no. 3, pp. 233-236, 2001.

[21] R. Rosmond, Y. C. Chagnon, G. Holm et al., "Hypertension in obesity and the leptin receptor gene locus," Journal of Clinical Endocrinology and Metabolism, vol. 85, no. 9, pp. 3126-3131, 2000.

[22] N. Yiannakouris, M. Yannakoulia, L. Melistas, J. L. Chan, D. Klimis-Zacas, and C. S. Mantzoros, "The Q223R polymorphism of the leptin receptor gene is significantly associated with obesity and predicts a small percentage of body weight and body composition variability," Journal of Clinical Endocrinology and Metabolism, vol. 86, no. 9, pp. 4434-4439, 2001.

[23] Y. C. Chagnon, J. H. Wilmore, I. B. Borecki et al., "Associations between the leptin receptor gene and adiposity in middle-aged caucasian males from the HERITAGE family study," Journal of Clinical Endocrinology and Metabolism, vol. 85, no. 1, pp. 29-34, 2000.

[24] M. Wauters, I. Mertens, M. Chagnon et al., "Polymorphisms in the leptin receptor gene, body composition and fat distribution in overweight and obese women," International Journal of Obesity and Related Metabolic Disorders, vol. 25, no. 5, pp. 714$720,2001$.

[25] H.-Y. Woo, H. Park, C.-S. Ki, Y. L. Park, and W. G. Bae, "Relationships among serum leptin, leptin receptor gene polymorphisms, and breast cancer in Korea," Cancer Letters, vol. 237, no. 1, pp. 137-142, 2006.

[26] Y. Zheng, K. Xiang, R. Zhang, W. Jia, J. Lu, and J. Tang, "Association of Gln223Arg variant in leptin receptor gene with metabolic abnormalities and hypertension in type II diabetes mellitus in Shanghai "Han" population," Zhonghua Nei Ke Za Zhi, vol. 38, no. 3, pp. 174-177, 1999.

[27] P. Gu, W. Jiang, M. Chen et al., "Association of leptin receptor gene polymorphisms and essential hypertension in a Chinese population," Journal of Endocrinological Investigation, vol. 35, no. 9, pp. 859-865, 2012.

[28] IBGE, CENSO 2010, Insituto Brasileiro de Georgrafia e Estatística, 2010.

[29] A. V. Chobanian, G. L. Bakris, H. R. Black et al., “The Seventh Report of the Joint National Committee on Prevention, Detection, Evaluation, and Treatment of High Blood Pressure: the 
JNC 7 report," The Journal of the American Medical Association, vol. 289, no. 19, pp. 2560-2572, 2003.

[30] WHO, The Use and Interpretation of Anthropometry, World Health Organization, Geneva, Switzerland, 1995.

[31] A. L. S. Guimarães, A. R. de Sá, J. M. N. Victória et al., "Association of interleukin- $\beta$ polymorphism with recurrent aphthous stomatitis in Brazilian individuals," Oral Diseases, vol. 12, no. 6, pp. 580-583, 2006.

[32] A. L. S. Guimarães, J. D. F. Correia-Silva, A. R. D. Sá et al., "Investigation of functional gene polymorphisms IL-1 $\beta$, IL6, IL-10 and TNF- $\alpha$ in individuals with recurrent aphthous stomatitis," Archives of Oral Biology, vol. 52, no. 3, pp. 268-272, 2007.

[33] C. C. Ragin, C. Dallal, M. Okobia et al., "Leptin levels and leptin receptor polymorphism frequency in healthy populations," Infectious Agents and Cancer, vol. 4, supplement 1, article S13, 2009.

[34] M. T. Guagnano, M. R. Manigrasso, E. Ballone et al., "Association between serum leptin levels and 24-hour blood pressure in obese women," Obesity Research, vol. 11, no. 4, pp. 549-555, 2003.

[35] G. M. Reaven, H. Lithell, and L. Landsberg, "Hypertension and associated metabolic abnormalities-the role of insulin resistance and the sympathoadrenal system," The New England Journal of Medicine, vol. 334, no. 6, pp. 374-381, 1996.

[36] K. Itoh, K. Imai, T. Masuda et al., "Relationship between changes in serum leptin levels and blood pressure after weight loss," Hypertension Research, vol. 25, no. 6, pp. 881-886, 2002.

[37] T. G. Pickering and R. B. Devereux, "Ambulatory monitoring of blood pressure as a predictor of cardiovascular risk," American Heart Journal, vol. 114, no. 4, pp. 925-928, 1987. 


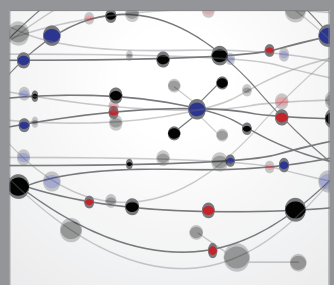

The Scientific World Journal
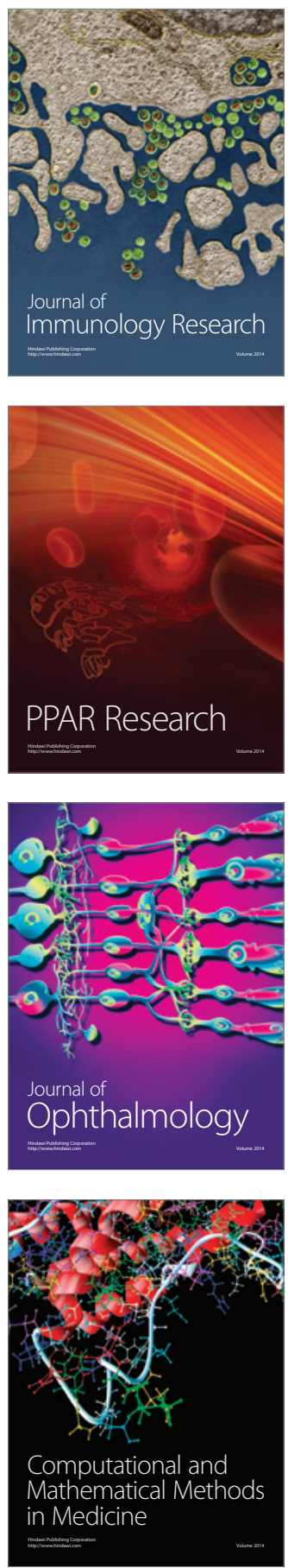

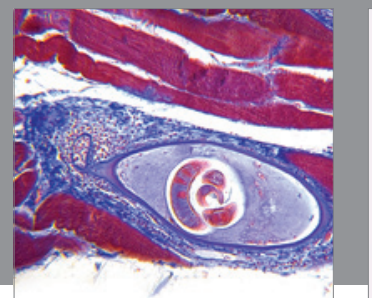

Gastroenterology

Research and Practice
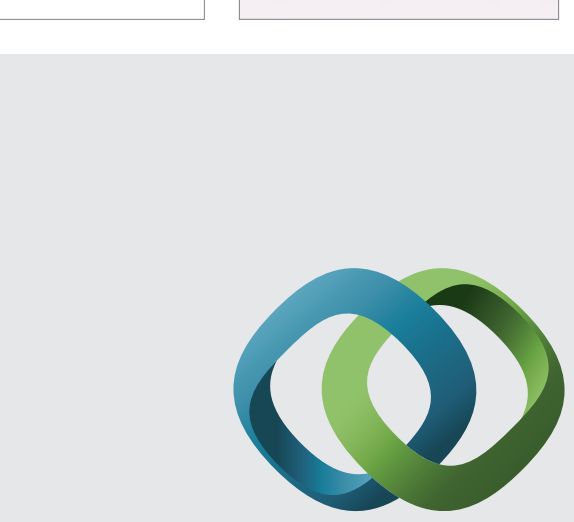

\section{Hindawi}

Submit your manuscripts at

http://www.hindawi.com
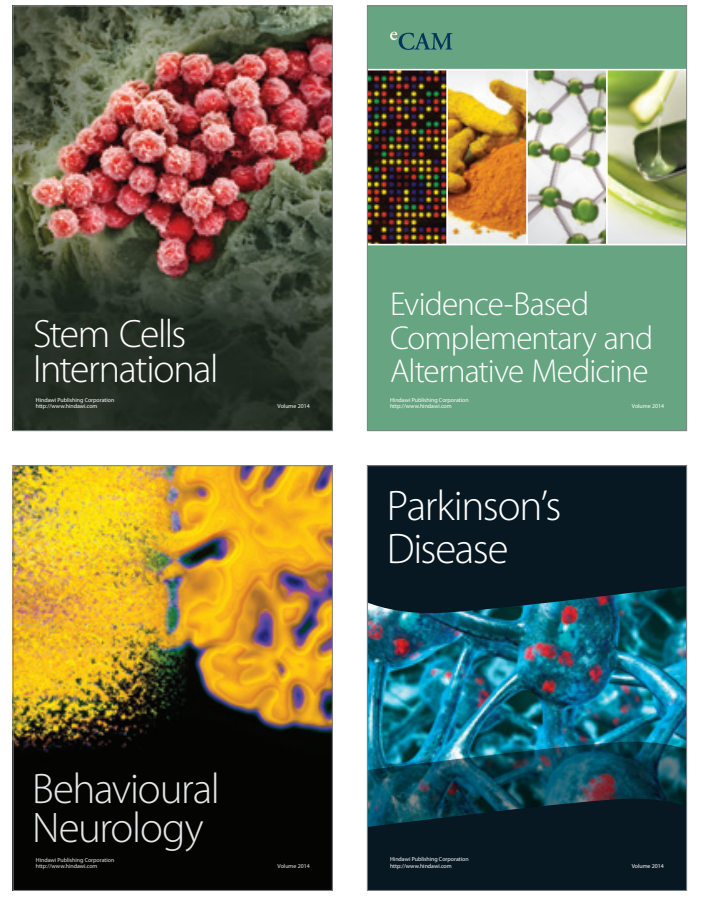
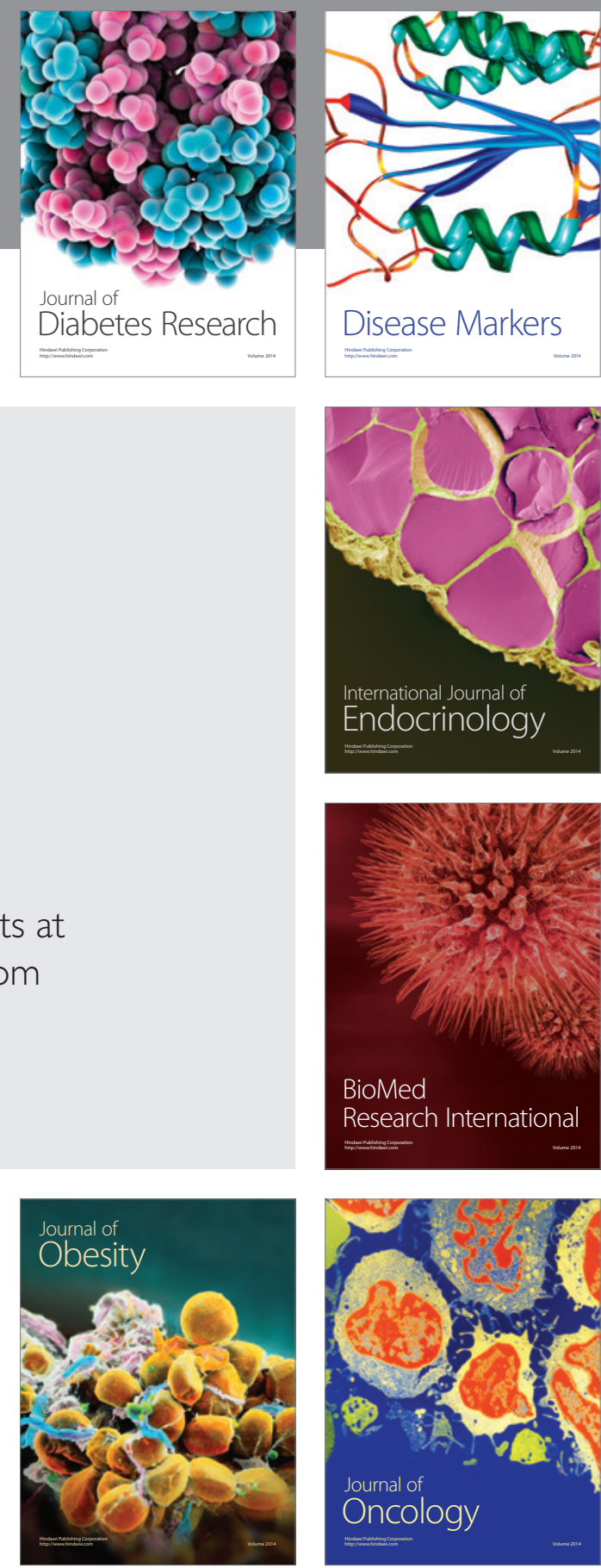

Disease Markers
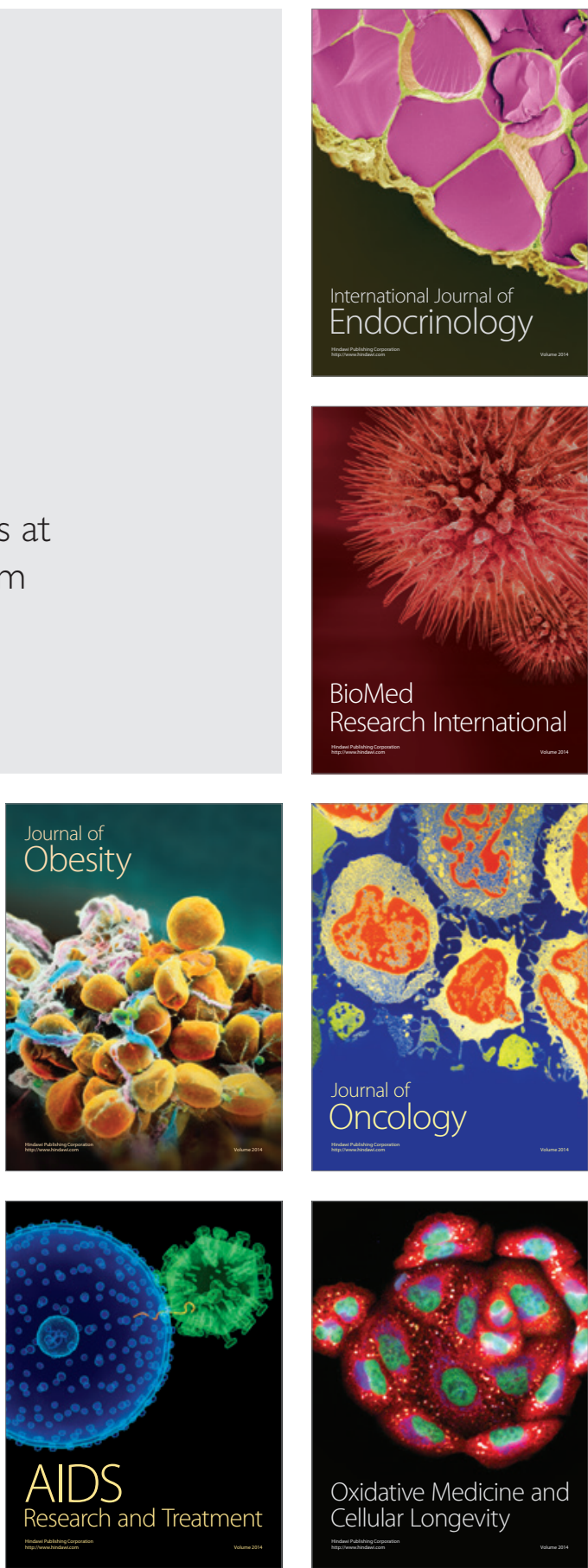